\section{JURNAL EKONOMI EFEKTIF}

ISSN : $2622-8882$, E-ISSN : 2622-9935

Jurnal Ekonomi Efektif, Vol. 1, No. 4, Juli 2019

@Prodi Manajemen Fakultas Ekonomi Universitas

Pamulang

\title{
PENGARUH PENGEMBANGAN KARIR DAN PELATIHAN KERJA TERHADAP KINERJA PEGAWAI PADA DINAS PERHUBUNGAN KOTA SERANG
}

\author{
${ }^{1 *}$ Heri Sapari Kahpi, ${ }^{2}$ Azhar Affandi, ${ }^{3}$ Denok Sunarsi, ${ }^{4}$ Mujahidin, ${ }^{5}$ Diah Asdiani \\ ${ }^{1}$ STIE Banten, Kota Serang, Banten, Indonesia \\ ${ }^{2}$ Universitas Pasundan, Bandung, Jawa Barat, Indonesia \\ ${ }^{3}$ Universitas Pamulang, Tangerang Selatan, Banten, Indonesia \\ ${ }^{4,5}$ Institut Agama Islam Negeri (IAIN) Palopo \\ *kahpi.stiebanten@gmail.com
}

\begin{abstract}
ABSTRAK
Penelitian ini bertujuan untuk mengetahui pengaruh pengembangan karir dan pelatihan kerja terhadap kinerja pegawai pada Dinas Perhubungan Kota Serang. Metode yang digunakan adalah explanatory research dengan teknik analisis menggunakan analisis statistik dengan pengujian regresi, korelasi, determinasi dan uji hipotesis. Hasil penelitian ini pengembangan karir berpengaruh signifikan terhadap kinerja pegawai sebesar $47,9 \%$, uji hipotesis diperoleh $\mathrm{t}$ hitung $>\mathrm{t}$ tabel atau $(7,902>1,995)$. Pelatihan kerja berpengaruh signifikan terhadap kinerja pegawai sebesar 48,3\%, uji hipotesis diperoleh $\mathrm{t}$ hitung $>\mathrm{t}$ tabel atau $(7,973>1,995)$. Pengembangan karir dan pelatihan kerja secara simultan berpengaruh signifikan terhadap kinerja pegawai dengan persamaan regresi $\mathrm{Y}=6,909+0,396 \mathrm{X} 1+0,449 \mathrm{X} 2$. Kontribusi pengaruh sebesar 65,2\%, uji hipotesis diperoleh $\mathrm{F}$ hitung $>\mathrm{F}$ tabel atau $(62,758>2,740)$.
\end{abstract}

\section{Kata Kunci: Pengembangan Karir, Pelatihan Kerja, Kinerja Pegawai.}

\section{ABSTRACT}

This study aims to determine the effect of career development and job training on employee performance at the Department of Transportation in Serang City. The method used is explanatory research with analysis techniques using statistical analysis with regression testing, correlation, determination and hypothesis testing. The results of this study career development has a significant effect on employee performance by 47.9\%, hypothesis testing obtained $t$ count $>$ t table or (7.902> 1.995). Job training has a significant effect on employee performance by $48.3 \%$, hypothesis testing is obtained t count $>t$ table or (7.973> 1.995). Career development and job training simultaneously have a significant effect on employee performance with the regression equation $Y=6.909+0.396 X 1+0.449 X 2$. Contribution of influence is $65.2 \%$, hypothesis testing obtained $F$ count $>F$ table or (62.758> 2.740).

Keywords: Career Development, Job Training, Employee Performance. 


\section{PENDAHULUAN}

\section{A. Latar Belakang Masalah}

Peranan sumber daya manusia memiliki peranan yang sangat strategis dalam menyelenggarakan dan menjalankan bisnis dalam suatu organisasi. peran pegawai sangat penting karena unsur manusia memegang peranan penting dalam melakukan aktivitas kegiatan organisasi dan berperan aktif dalam kebijakan dan pencapaian tujuan organisasi. Dengan sumber daya manusia yang handal maka kegiatan operasional organisasi akan berjalan dengan lancar.

Manusia selalu berperan aktif dan dominan dalam kegiatan organisasi dan tentunya pegawaimemegang peran utama dalam menjalankan kegiatan organisasi dalam meningkatkan serta mengembangkan organisasi dengan mengadakan berbagai cara yang tersusun dalam program peningkatan kinerja. Peranan sumber daya manusia sangat penting dalam suatu organisasi, baik organisasi swasta maupun organisasi pemerintah atau Badan Usaha Milik Negara (BUMN).

Sumber daya manusia merupakan salah satu faktor yang ikut terlibat secara langsung dalam menjalankan kegiatan organisasi dan berperang penting dalam meningkatkan kinerja organisasi dalam mencapai tujuan yang telah ditetapkan, sebagaimana Hasibuan (2016) menyapaikan bahwa tujuan tidak mungkin terwujud tanpa peran aktif pegawai meskipun alat-alat yang dimiliki organisasi begitu canggihnya" Oleh karena itu keberhasilan suatu organisasi tidak hanya tergantung dengan teknologi organisasi saja namun juga tergantung pada aspek sumber daya manusia yang dimiliki oleh organisasi. Sehingga suatu organisasi membutuhkan sumber daya manusia yang potensial, baik pemimpin maupun pegawai dapat memberikan kontribusi yang baik dan melaksanakan tugas dengan optimal untuk mencapai tujuan organisasi. Karena semua kegiatan organisasi akan melibatkan tindakan sumber daya manusia yang ada didalamnya. Lebih lanjut Hasibuan (2016) juga menyampaikan bahwa "Manajemen merupakan ilmu dalam mengatur pemanfaatan sumber daya manusia secara efektif untuk mencapai suatu tujuan tertentu.

Dinas perhubungan Kota Serang atau yang dikenal dulunya sebagai Direktorat Jendral (Dirjen) Perhubungan Kota Serang adalah Instansi Pemerintah daerah yang bergerak di Bidang perhubungan, baik itu perhubungan darat, laut, maupun udara.

Dinas Perhubungan provinsi Kota Serang merupakan unsur pelaksana Pemerintah Daerah di bidang perhubungan darat, laut, dan udara. Dishub dipimpin oleh seorang Kepala Dinas yang berada dibawah dan bertanggung jawab kepada Gubernur melalui Sekretaris Daerah (Sekda). Dalam menjalankan tugasnya, Dishub berkoordinasi dengan asisten pembangunan.

Dinas Perhubungan Kota Serang bertekad untuk menjadi organisasi PMA yang konsisten dengan menjaga kualitas sumber daya manusianya sehingga semua aspek yang diperlukan dapat menunjang kinerja yang baik. Guna menyelaraskan visi dan misi, Dinas Perhubungan Kota Serang harus terus berusaha memperbaiki kemampuan sumber daya manusia sehingga mampu mewujudkan tujuan organisasi dengan baik. Dalam menjalankan aktivitas kerjanya, pegawai dituntut memiliki kemampuan kerja yang baik. Untuk meningkatkan kemampuan kerja yang optimal, diperlukan pengelolaan sumber daya manusia yang baik, salah satu cara yang umum dilakukan organisasi adalah melalui pelatihan. Pelatihan akan memberikan kesempatan pegawai untuk dapat mengembangkan keahlian, kemampuan dalam bekerja, dan untuk menambah pengetahuan sehingga pegawai dapat mengerti, memahami, dan menguasai apa yang harus dikerjakan dan mengapa harus dikerjakan, apa yang seharusnya dilakukan dan bagaimana melakukannya. Diharapkan melalui program pelatihan yang sudah dilaksanakan dalam organisasi akan memberikan dampak positif terhadap peningkatan keahlian, wawasan, pengetahuan, dan 
perilaku pegawai pada tugas-tugasnya sehingga kinerja pegawai organisasi tersebut dapat meningkat.

Pelatihan kerja menjadi penting dilakukan oleh suatu organisasi terlebih oleh instansi pemerintahan agar mampu meningkatkan kualitas layanan secara baik.

Pemerintah Kota serang memiliki letak geografis yang sangat strategis yang menghubungkan kota Sumatra dengan kota-kota di Jawa. Dengan kondisi ini Dinas Perhubungan Kota Serang harus mampu mengkolaborasi dengan upaya meningkatkan sarana prasarana daerah yang berwawasan lingkungan, meningkatkan perekonomian Daerah dan pemberdayaan masyarakat yang berdaya saing seta mampu meningkatkan tata kelola Pemerintahan yang baik.

Dalam rangka mengurangi terjadinya kesenjangan (gap) kompetensi antara lulusan pendidikan/pelatihan dengan kebutuhan pada sektor sumber daya dalam organisasi, maka orientasi pendidikan/pelatihan yang selama ini supply driven harus diubah menjadi demand driven. Oleh karena itu para praktisi lembaga harus terlibat langsung untuk menginformasikan kebutuhan kompetensi yang ada pada bidangnya masing-masing dalam bentuk standar kompetensi kerja yang dapat digunakan untuk acuan penyusunan program pendidikan/pelatihan. Dengan konsep tersebut, kemampuan lulusan lembaga pendidikan/pelatihan akan sesuai dengan kebutuhan industri dan para lulusan nantinya juga dapat memiliki sertifikat kompetensi setelah melalui uji kompetensi.

Menurut Mangkunegara (2015) "Pelatihan (training) adalah suatu proses pendidikan jangka pendek yang mempergunakan prosedur sistematis dan terorganisasi, pegawai non manajerial mempelajari pengetahuan dan keterampilan teknis dalam tujuan yang terbatas". Pendapat ini juga selaras dengan Rivai (2015) bahwa pelatihan dalam penelitian ini "Proses secara sistematis mengubah tingkah laku pegawai untuk mencapai tujuan organisasi. Pelatihan berkatian dengan keahlian dan kemampuan pegawai untuk melaksanakan pekerjaan". Semakin banyak pegawai yang diberikan kesempatan untuk mengikuti pelatihan dapat meningkatkan kinerja organisasi.

Berdasarkan latar belakang permasalahan diatas, maka penulis tertarik untuk melakukan penelitian lebih lanjut dengan judul: "Pengaruh Pengembangan Karir dan Pelatihan Kerja Terhadap Kinerja Pegawai Pada Dinas Perhubungan Kota Serang"

\section{B. Rumusan Masalah}

1. Adakah pengaruh antara pengembangan karir terhadap kinerja pegawai pada Dinas Perhubungan Kota Serang?

2. Adakah pengaruh antara pelatihan kerja terhadap kinerja pegawai pada Dinas Perhubungan Kota Serang?

3. Adakah pengaruh secara simultan antara pengembangan karir dan pelatihan kerja terhadap kinerja pegawai pada Dinas Perhubungan Kota Serang?

\section{Tujuan Penelitian}

1. Untuk mengetahui pengaruh antara pengembangan karir terhadap kinerja pegawai pada Dinas Perhubungan Kota Serang.

2. Untuk mengetahui pengaruh antara pelatihan kerja terhadap kinerja pegawai pada Dinas Perhubungan Kota Serang.

3. Untuk mengetahui pengaruh secara simultan antara pengembangan karir dan pelatihan kerja terhadap kinerja pegawai pada Dinas Perhubungan Kota Serang.

\section{TINJAUAN PUSTAKA}




\section{Pengembangan Karir}

Menurut Rivai (2015) pengembangan karir merupakan proses peningkatan kemampuan kerja individu yang dicapai dalam rangka mencapai karir yang diinginkan". Pengembangan karir sangat diharapkan oleh setiap pegawai karena akan mendapatkan hakhak atas apa yang diperoleh sebelumnya baik material maupun non materiil. Adapun indikatornya sebagai berikut: 1) Kemampuan kerja, 2) Exposure, 3) Kesetiaan Organisasi, 4) Mentor dan Sponsor, 5) Kesempatan-kesempatan untuk tumbuh

\section{Pelatihan Kerja}

Menurut Veithzal Rivai (2015) yang dimaksud pelatihan dalam penelitian ini "Proses secara sistematis mengubah tingkah laku pegawai untuk mencapai tujuan organisasi. Pelatihan berkatian dengan keahlian dan kemampuan pegawai untuk melaksanakan pekerjaan". Adapun indikator yang digunakan dalam penelitian ini meliputi: Materi pelatihan, metode pelatihan, kemampuan instruktur, peserta pelatihan dan evaluasi pelatihan

\section{Kinerja Pegawai}

Menurut Mangkunegara (2016) yaitu hasil kerja secara kualitas dan kuantitas yang dicapai oleh seorang pegawai dalam melaksanakan tugasnya sesuai dengan tanggung jawab yang diberikan kepadanya. Adapun indikator yang digunakan meliputi: 1) Kualitas, 2) kuantitas, 3) pelaksanaan tugas, 4) tanggung jawab pekerjaan.

\section{Model Penelitian}

Menurut pendapat Sugiyono (2016) "Model penelitian merupakan sintesa yang mencerminkan keterkaitan antara variabel yang diteliti dan merupakan tuntunan untuk memecahkan masalah penelitian serta merumuskan hipotesis yang berbentuk bagan alur yang dilengkapi penjelasan kualitatif". Dalam penelitian ini model penelitian yang dibuat sebagai berikut:

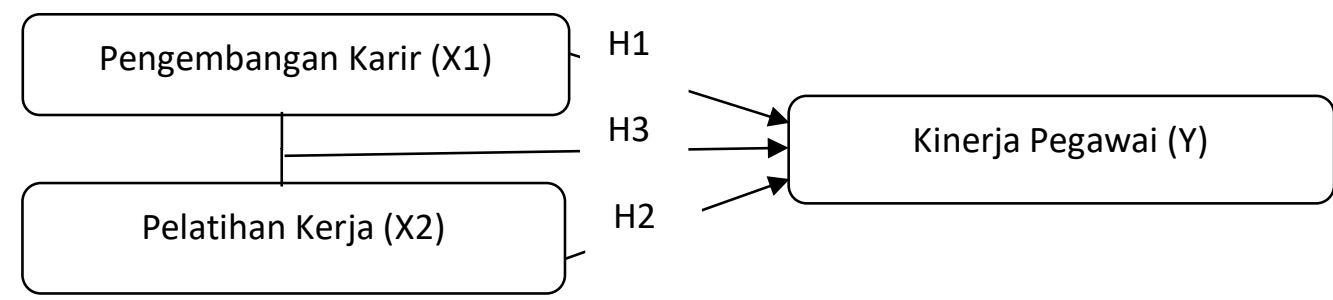

Gambar Paradigma Model Penelitian

\section{Hipotesis Penelitian}

Hipotesis yang peneliti ajukan adalah sebagai berikut:

H1 : Diduga terdapat pengaruh yang signifikan antara pengembangan karir terhadap kinerja pegawai pada Dinas Perhubungan Kota Serang.

$\mathrm{H} 2$ : Diduga terdapat pengaruh yang signifikan antara pelatihan kerja terhadap kinerja pegawai pada Dinas Perhubungan Kota Serang.

H3 : Diduga terdapat pengaruh yang signifikan antara pengembangan karir dan pelatihan kerja secara simultan terhadap kinerja pegawai pada Dinas Perhubungan Kota Serang.

\section{METODE PENELITIAN}

\section{Populasi}


Populasi merupakan sekumpulan objek yang ditentukan melalui suatu kriteria tertentu yang akan dikategorikan ke dalam objek yang akan diteliti. Menurut Sugiyono (2016) mendefinisikan populasi adalah jumlah wilayah generalisasi yang terdiri atas obyek atau subyek yang mempunyai kualitas dan karakteristik yang ditetapkan oleh peneliti dan kemudian ditarik kesimpulannya. Adapun populasi dalam penelitian berjumlah 70 responden Dinas Perhubungan Kota Serang

\section{Sampel}

Menurut Sugiyono (2016) yaitu "Sampel adalah jumlah dan karakteristik yang dimiliki oleh populasi tersebut". Sedangkan Suharsini Arikunto (2010) berpendapat bahwa "Sampel adalah sebagian atau wakil populasi yang diteliti". Teknik pengambilan sampling dalam penelitian ini adalah samplel jenuh, dimana semua anggota populasi dijadikan sebagai sampel. Dengan demikian sampel dalam penelitian ini berjumlah 70 responden.

\section{Jenis Penelitian}

Jenis penelitian yang dipakai adalah asosiatif, dimana tujuannya adalah untuk mengetahui mencari keterhubungan antara

\section{Metode Analisis Data}

Dalam menganalisis data digunakan uji instrumen, uji asumsi klasik, regresi, koefisien determinasi dan uji hipotesis.

\section{HASIL PENELITIAN}

\section{Uji Intrumen}

Pada pengujian ini digunakan uji validitas dan uji reliabilitas. Uji validitas dimaksudkan untuk mengetahui ketepatan data tentang kesesuaian antara yang mau diukur dengan hasil pengukurannya. Menurut Sugiyono (2016) "Valid berarti terdapat kesamaan antara data yang terkumpul dengan data yang sesungguhnya". Sedangkan Ghozali (2013) berpendapat "Suatu kuesioner dikatakan valid jika pertanyaan pada kuesioner mampu untuk mengungkapkan sesuatu yang akan diukur oleh kuesioner tersebut". Untuk melakukan uji validitas dilihat nilai signifikansi 2 tailed dibandingkan dengan 0,05 dengan dengan ketentuan:

1) Jika nilai signifikansi 2 talied $<0,05$, maka instrumen valid,

2) Jika nilai signifikansi 2 talied $>0,05$, maka instrumen tidak valid,

Dari hasil pengujian diperoleh masing-masing item pernyataan pseluruh variabel diperoleh nilai signifikansi 2 tailed sebesar $0,000<0,05$, dengan demikian instrumen valid.

Uji berikutnya adalah uni reliabilitas. Model analisis uji reliabiltas yang digunakan dalam penelitian ini adalah model Alpha Cronbach. Menurut Ghozali (2013) berpendapat "reliabilitas merupakan alat untuk menguji kekonsistenan jawaban responden atas pertanyaan di kuesioner. Suatu kuesioner dikatakan reliabel jika jawaban seseorang terhadap pertanyaan adalah konsisten atau stabil dari waktu ke waktu". Dalam pengukurannya dilakukan dengan analisis Cronbach's Alpha. Ghozali (2013) mengklasifikasikan nilai Cronbach's Alpha sebagai berikut:

1) Jika nilai Cronbach's Alpha $>0,60$, maka dinyatakan reliabel,

2) Jika nilai Cronbach's Alpha $<0,60$, maka dinyatakan tidak reliabel,

Adapun hasil pengujiannya sebagai berikut:

Tabel Hasil Pengujian Reliabilitas

\begin{tabular}{|l|c|c|c|}
\hline \multicolumn{1}{|c|}{ Variabel } & $\begin{array}{c}\text { Cronbach's } \\
\text { Alpha }\end{array}$ & $\begin{array}{c}\text { Standar Kritis } \\
\text { Alpha }\end{array}$ & Keterangan \\
\hline Pengembangan karir (X1) & 0,763 & 0,600 & Reliabel \\
\hline Pelatihan kerja (X2) & 0,687 & 0,600 & Reliabel \\
\hline
\end{tabular}




\begin{tabular}{|l|c|c|c|}
\hline Kinerja Pegawai (Y) & 0,703 & 0,600 & Reliabel \\
\hline
\end{tabular}

Berdasarkan hasil pengujuan di atas, Keseluruhan variabel pengembangan karir (X1), pelatihan kerja (X2) diperoleh nilai cronbach alpha lebih besar dari 0,60. Dengan demikian dinyatakan reliabel.

\section{Uji Asumsi Klasik}

Uji asumsi klasik dimaksudkan untuk mengetahui ketepatan sebuah data. Menurut Singgih Santoso (2011) "Sebuah model regresi akan digunakan untuk melakukan peramalan, sebuah model yang baik adalah model dengan kesalahan peramalan yang seminimal mungkin". Karena itu, sebuah model sebelum digunakan seharusnya memenuhi beberapa asumsi, yang biasa disebut asumsi klasik. Dalam penelitian ini uji asumsi klasik yang digunakan adalah meliputi: Uji Normalitas, Uji Multikolinearitas, Uji Autokorelasi, dan Uji Heterokedastisitas. Adapun hasilnya sebagai berikut:

\section{a. Uji Normalitas}

Uji normalitas dilakukan untuk menguji apakah dalam model regresi, variabel dependen dan variabel independen berdistribusi normal atau berdistribusi tidak normal. Hasil uji normalitas dengan alat uji Kolmogorov-Smirnov Test, sebagai berikut:

Tabel Hasil Normalitas Kolmogorov-Smirnov

\begin{tabular}{l|r|r|r|r|r|r} 
& \multicolumn{3}{c}{$\begin{array}{c}\text { Tests of Normality } \\
\text { Kolmogorov-Smirnov }\end{array}$} & \multicolumn{3}{c}{ Shapiro-Wilk } \\
& Statistic & df & Sig. & Statistic & df & Sig. \\
\hline Kinerja Pegawai $(Y)$ & .097 & 70 & .099 & .975 & 70 & .181 \\
\hline
\end{tabular}

*. This is a lower bound of the true significance.

a. Lilliefors Significance Correction

Berdasarkan hasil pengujian pada tabel diatas diperoleh nilai signifikansi 0,099 dimana nilai tersebut lebih besar dari nilai $\alpha=0,050$ atau $(0,099>0,050)$. Dengan demikian maka asumsi distribusi persamaan pada uji ini adalah normal.

\section{b. Uji Multikonilieritas}

Pengujian mutlikolinearitas dilakukan untuk meyakini bahwa antar variabel bebas tidak memiliki multikolinearitas atau tidak memiliki pengaruh korelasi antara variabel yang ditetapkan sebagai model dalam penelitian. Uji multikolinearitas dilakukan dengan melihat nilai Tolerance Value dan Variance Inflation Factor (VIF). Adapun hasil pengujiannya sebagai berikut:

Tabel Hasil Uji Multikolinieritas dengan Collinierity Statistic.

\begin{tabular}{|c|c|c|c|c|c|c|}
\hline \multirow{3}{*}{\multicolumn{2}{|c|}{ Model }} & \multicolumn{3}{|c|}{ Coefficients $^{a}$} & & \\
\hline & & \multicolumn{2}{|c|}{$\begin{array}{l}\text { Unstandardized } \\
\text { Coefficients }\end{array}$} & \multirow{2}{*}{$\begin{array}{c}\text { Standardized } \\
\text { Coefficients } \\
\text { Beta } \\
\end{array}$} & \multicolumn{2}{|c|}{ Collinearity Statistics } \\
\hline & & $\mathrm{B}$ & Std. Error & & Tolerance & VIF \\
\hline \multirow[t]{3}{*}{1} & (Constant) & 6.909 & 2.824 & & & \\
\hline & Pengembangan karir (X1) & .396 & .069 & .467 & .774 & 1.292 \\
\hline & Pelatihan kerja (X2) & .449 & .078 & .473 & .774 & 1.292 \\
\hline
\end{tabular}

a. Dependent Variable: Kinerja Pegawai $(\mathrm{Y})$

Berdasarkan hasil pengujian pada tabel diatas nilai tolerance masing-masing variabel bebas yaitu 0,741 <1,0 dan nilai Variance Inflation Factor (VIF) sebesar 1,292 < 10, dengan demikian model regresi ini tidak terjadi multikolinearitas.

\section{c. Uji Autokorelasi}


Pengujian Autokorelasi digunakan untuk mengetahui ada atau tidaknya penyimpangan korelasi antar anggota sampel. Pengujian dilakukan dengan alat uji Darbin-Watson (DW test). Adapun hasil pengujiannya sebagai berikut:

Tabel Hasil Uji Autokorelasi

\begin{tabular}{|c|c|c|c|c|c|}
\hline \multicolumn{6}{|c|}{ Model Summaryb } \\
\hline Model & $\mathrm{R}$ & R Square & $\begin{array}{l}\text { Adjusted R } \\
\text { Square }\end{array}$ & $\begin{array}{l}\text { Std. Error of the } \\
\text { Estimate }\end{array}$ & Durbin-Watson \\
\hline 1 & $.807^{a}$ & .652 & .642 & 2.123 & 1.664 \\
\hline
\end{tabular}

Hasil pengujian pada tabel diatas diperoleh nilai Durbin-Watson sebesar 1.664 nilai tersebut berada diantara interval $1.550-2.460$. Dengan demikian model regresi dinyatakan tidak ada gangguan autokorelasi.

\section{d. Uji Heteroskesdastisitas}

Pengujian heteroskedastisitas dimaksudkan untuk menguji apakah dalam sebuah model regresi terjadi ketidaksamaan varians residual. Hasil pengujiannya sebagai berikut:

Tabel Hasil Uji Heteroskesdastisitas dengan Glejser Test Model

\begin{tabular}{|c|c|c|c|c|c|c|}
\hline \multirow{2}{*}{\multicolumn{2}{|c|}{ Model }} & \multicolumn{2}{|c|}{$\begin{array}{c}\text { Coefficients }^{a} \\
\text { Unstandardized } \\
\text { Coefficients }\end{array}$} & \multirow{2}{*}{$\begin{array}{c}\text { Standardized } \\
\text { Coefficients } \\
\text { Beta } \\
\end{array}$} & \multirow[b]{2}{*}{$\mathrm{t}$} & \multirow[b]{2}{*}{ Sig. } \\
\hline & & $\mathrm{B}$ & Std. Error & & & \\
\hline \multirow[t]{3}{*}{1} & (Constant) & -3.148 & 1.603 & & -1.964 & .054 \\
\hline & Pengembangan karir (X1) & .054 & .039 & .178 & 1.368 & .176 \\
\hline & Pelatihan kerja (X2) & .075 & .044 & .223 & 1.709 & .092 \\
\hline
\end{tabular}

a. Dependent Variable: RES2

Hasil pengujian dengan menggunakan uji glejser diperoleh nilai Sig. $>0,05$. Dengan demikian regression model tidak ada gangguan heteroskesdastisitas.

\section{Analisis Deskriptif}

Pada pengujian ini digunakan untuk mengetahui skor minimum dan maksimum, mean score dan standar deviasi dari masing-masing variabel. Adapun hasilnya sebagai berikut:

Tabel Hasil Analisis Descriptive Statistics

\begin{tabular}{lr|r|r|r|r}
\multicolumn{7}{c}{ Descriptive Statistics } \\
& N & Minimum & Maximum & Mean & Std. Deviation \\
\hline $\begin{array}{l}\text { Pengembangan karir } \\
\text { (X1) }\end{array}$ & 70 & 31 & 48 & 37.00 & 4.188 \\
\hline Pelatihan kerja (X2) & 70 & 28 & 45 & 37.24 & 3.736 \\
\hline Kinerja Pegawai (Y) & 70 & 31 & 47 & 38.27 & 3.546 \\
\hline Valid N (listwise) & 70 & & & & \\
\hline
\end{tabular}

Pengembangan karir diperoleh varians minimum sebesar 31 dan varians maximum 48 dengan mean score sebesar 3,70 dengan standar deviasi 4,188.

Pelatihan kerja diperoleh varians minimum sebesar 28 dan varians maximum 45 dengan mean score sebesar 3,72 dengan standar deviasi 3,736.

Kinerja pegawai diperoleh varians minimum sebesar 31 dan varians maximum 47 dengan mean score sebesar 3,82 dengan standar deviasi 3,546.

\section{Analisis Verifikatif.}

Pada analisis ini dimaksudkan untuk mengetahui pengaruh variabel independen terhadap variabel dependen. Adapun hasil pengujian sebagai berikut: 


\section{a. Analisis Regresi Linier Berganda}

Uji regresi ini dimaksudkan untuk mengetahui perubahan variabel dependen jika variabel independen mengalami perubahan. Adapun hasil pengujiannya sebagai berikut:

Tabel Hasil Pengujian Regresi Linier Berganda

\begin{tabular}{|c|c|c|c|c|c|c|}
\hline \multicolumn{7}{|c|}{ Coefficients $^{a}$} \\
\hline \multirow[b]{2}{*}{ Model } & & \multicolumn{2}{|c|}{$\begin{array}{l}\text { Unstandardized } \\
\text { Coefficients }\end{array}$} & \multirow{2}{*}{$\begin{array}{c}\text { Standardized } \\
\text { Coefficients } \\
\text { Beta }\end{array}$} & \multirow[b]{2}{*}{$\mathrm{t}$} & \multirow[b]{2}{*}{ Sig. } \\
\hline & & $\mathrm{B}$ & Std. Error & & & \\
\hline \multirow[t]{3}{*}{1} & (Constant) & 6.909 & 2.824 & & 2.447 & .017 \\
\hline & $\begin{array}{l}\text { Pengembangan } \\
\text { karir (X1) }\end{array}$ & .396 & .069 & .467 & 5.701 & .000 \\
\hline & $\begin{array}{l}\text { Pelatihan kerja } \\
(\mathrm{X} 2)\end{array}$ & .449 & .078 & .473 & 5.776 & .000 \\
\hline
\end{tabular}

Berdasarkan hasil pengujian pada tabel di atas, diperoleh persamaan regresi $\mathrm{Y}=6,909+$ 0,396X1 + 0,449X2. Dari persamaan tersebut dijelaskan sebagai berikut:

1) Konstanta sebesar 6,909 diartikan jika pengembangan karir dan pelatihan kerja tidak ada, maka telah terdapat nilai kinerja pegawai sebesar 6,909 point.

2) Koefisien regresi pengembangan karir sebesar 0,396, angka ini positif artinya setiap ada peningkatan pengembangan karir sebesar 0,396 maka kinerja pegawai juga akan mengalami peningkatan sebesar 0,396 point.

3) Koefisien regresi pelatihan kerja sebesar 0,449 , angka ini positif artinya setiap ada peningkatan pelatihan kerja sebesar 0,449 maka kinerja pegawai juga akan mengalami peningkatan sebesar 0,449 point.

\section{b. Analisis Koefisien Korelasi}

Analisis koefisien korelasi dimaksudkan untuk mengetahui tingkt kekuatan hubungan dari variabel independen terhadap variabel dependen baik secara parsial maupun simultan. Adapun hasil pengujian sebagai berikut:

Tabel Hasil Pengujian Koefisien Korelasi Pengembangan karir Terhadap Kinerja Pegawai.

\begin{tabular}{llr|r}
\multicolumn{2}{c}{ Correlations $^{\mathbf{b}}$} \\
& \multicolumn{1}{c}{$\begin{array}{c}\text { Pengembang } \\
\text { an karir (X1) }\end{array}$} & Kinerja Pegawai (Y) \\
\hline Pengembangan karir (X1) & Pearson Correlation & 1 & $.692^{* *}$ \\
\cline { 2 - 4 } & Sig. (2-tailed) & .000 \\
\hline Kinerja Pegawai (Y) & Pearson Correlation & $.692^{* *}$ & 1 \\
\cline { 2 - 4 } & Sig. (2-tailed) & .000 & \\
\hline
\end{tabular}

Berdasarkan hasil pengujian diperoleh nilai korelasi sebesar 0,692 artinya pengembangan karir memiliki hubungan yang kuat terhadap kinerja pegawai.

Tabel Hasil Pengujian Koefisien Korelasi Pelatihan kerja Terhadap Kinerja Pegawai.

\begin{tabular}{|c|c|c|c|}
\hline \multicolumn{4}{|c|}{ Correlations $^{b}$} \\
\hline & & $\begin{array}{c}\text { Pelatihan kerja } \\
\text { (X2) }\end{array}$ & Kinerja Pegawai $(\mathrm{Y})$ \\
\hline \multirow[t]{2}{*}{ Pelatihan kerja (X2) } & Pearson Correlation & 1 & $.695^{* \star}$ \\
\hline & Sig. (2-tailed) & & .000 \\
\hline \multirow[t]{2}{*}{ Kinerja Pegawai (Y) } & Pearson Correlation & $.695^{\star \star}$ & 1 \\
\hline & Sig. (2-tailed) & .000 & \\
\hline
\end{tabular}

Berdasarkan hasil pengujian diperoleh nilai korelasi sebesar 0,695 artinya pelatihan 
kerja memiliki hubungan yang kuat terhadap kinerja pegawai.

Tabel 10. Hasil Pengujian Koefisien Korelasi Pengembangan karir dan Pelatihan kerja secara simultan Terhadap Kinerja Pegawai.

\section{Model Summary}

\begin{tabular}{|c|c|c|c|c|}
\hline \multicolumn{5}{|c|}{ IVIou } \\
\hline Model & $\mathrm{R}$ & R Square & $\begin{array}{l}\text { Adjusted R } \\
\text { Square }\end{array}$ & $\begin{array}{c}\text { Std. Error of the } \\
\text { Estimate }\end{array}$ \\
\hline$\overline{1}$ & $.807^{a}$ & .652 & .642 & 2.123 \\
\hline
\end{tabular}

a. Predictors: (Constant), Pelatihan kerja (X2), Pengembangan karir (X1)

Berdasarkan hasil pengujian diperoleh nilai korelasi sebesar 0,807 artinya pengembangan karir dan pelatihan kerja secara simultan memiliki hubungan yang sangat kuat terhadap kinerja pegawai.

\section{c. Analisis Koefisien Determinasi}

Analisis koefisien determinasi dimaksudkan untuk mengetahui besarnya persentase pengaruh dari variabel independen terhadap variabel dependen baik secara parsial maupun simultan. Adapun hasil pengujian sebagai berikut:

Tabel 11. Hasil Pengujian Koefisien Determinasi Pengembangan karir Terhadap Kinerja Pegawai.

\begin{tabular}{|c|c|c|c|c|}
\hline \multicolumn{5}{|c|}{ Model Summary } \\
\hline Model & $\mathrm{R}$ & R Square & $\begin{array}{l}\text { Adjusted R } \\
\text { Square }\end{array}$ & $\begin{array}{l}\text { Std. Error of the } \\
\text { Estimate }\end{array}$ \\
\hline 1 & $.692^{\mathrm{a}}$ & .479 & .471 & 2.579 \\
\hline
\end{tabular}

Berdasarkan hasil pengujian diperoleh nilai determinasi sebesar 0,479 artinya pengembangan karir memiliki kontribusi pengaruh sebesar $47,9 \%$ terhadap kinerja pegawai.

Tabel 13. Hasil Pengujian Koefisien Determinasi Pelatihan kerja Terhadap Kinerja Pegawai.

\section{Model Summary}

\begin{tabular}{lrr|rr|r} 
Model & R & R Square & $\begin{array}{c}\text { Adjusted R } \\
\text { Square }\end{array}$ & \multicolumn{2}{c}{$\begin{array}{c}\text { Std. Error of the } \\
\text { Estimate }\end{array}$} \\
\hline 1 & & $.695^{\mathrm{a}}$ & .483 & .476 & 2.568 \\
\hline
\end{tabular}

a. Predictors: (Constant), Pelatihan kerja (X2)

Berdasarkan hasil pengujian diperoleh nilai determinasi sebesar 0,483 artinya pelatihan kerja memiliki kontribusi pengaruh sebesar 48,3\% terhadap kinerja pegawai. Tabel 14. Hasil Pengujian Koefisien Determinasi Pengembangan karir dan Pelatihan kerja Terhadap Kinerja Pegawai.

\begin{tabular}{|c|c|c|c|c|}
\hline \multicolumn{5}{|c|}{ Model Summary } \\
\hline Model & $\mathrm{R}$ & R Square & $\begin{array}{l}\text { Adjusted R } \\
\text { Square }\end{array}$ & $\begin{array}{c}\text { Std. Error of the } \\
\text { Estimate }\end{array}$ \\
\hline 1 & $.807^{a}$ & .652 & .642 & 2.123 \\
\hline
\end{tabular}

a. Predictors: (Constant), Pelatihan kerja (X2), Pengembangan karir (X1)

Berdasarkan hasil pengujian diperoleh nilai determinasi sebesar 0,652 artinya pengembangan karir dan pelatihan kerja secara simultan memiliki kontribusi pengaruh sebesar $65,2 \%$ terhadap kinerja pegawai, sedangkan sisanya sebesar 44,8\% dipengaruhi faktor lain.

\section{d. Uji Hipotesis}




\section{Uji hipotesis Parsial (Uji t)}

Pengujian hipotesis dengan uji t digunakan untuk mengetahui hipotesis parsial mana yang diterima.

Hipotesis pertama: Terdapat pengaruh yang signifikan antara pengembangan karir terhadap kinerja pegawai.

Tabel Hasil Uji Hipotesis Pengembangan karir Terhadap Kinerja Pegawai.

\begin{tabular}{|c|c|c|c|c|c|}
\hline & & befficients & & & \\
\hline & $\begin{array}{l}\text { Unsta } \\
\text { Coe }\end{array}$ & $\begin{array}{l}\text { dardized } \\
\text { icients }\end{array}$ & $\begin{array}{l}\text { Standardized } \\
\text { Coefficients }\end{array}$ & & \\
\hline Model & $\mathrm{B}$ & Std. Error & Beta & $\mathrm{t}$ & Sig. \\
\hline 1 (Constant) & 16.591 & 2.761 & & 6.009 & .000 \\
\hline $\begin{array}{l}\text { Pengembangan karir } \\
\text { (X1) }\end{array}$ & .586 & .074 & .692 & 7.902 & .000 \\
\hline
\end{tabular}

a. Dependent Variable: Kinerja Pegawai $(\mathrm{Y})$

Berdasarkan hasil pengujian pada tabel di atas, diperoleh nilai $\mathrm{t}$ hitung $>\mathrm{t}$ tabel atau $(7,902>1,995)$, dengan demikian hipotesis pertama yang diajukan bahwa terdapat pengaruh yang signifikan atara pengembangan karir terhadap kinerja pegawai diterima.

Tabel 16. Hasil Uji Hipotesis Pelatihan kerja Terhadap Kinerja Pegawai.

\begin{tabular}{|c|c|c|c|c|c|}
\hline \multirow[b]{3}{*}{ Model } & \multicolumn{2}{|c|}{ Coefficients $^{a}$} & \multirow{3}{*}{$\begin{array}{c}\text { Standardized } \\
\text { Coefficients } \\
\text { Beta } \\
\end{array}$} & \multirow[b]{3}{*}{$\mathrm{t}$} & \multirow[b]{3}{*}{ Sig. } \\
\hline & \multicolumn{2}{|c|}{$\begin{array}{l}\text { Unstandardized } \\
\text { Coefficients }\end{array}$} & & & \\
\hline & $\mathrm{B}$ & Std. Error & & & \\
\hline 1 (Constant) & 13.695 & 3.098 & & 4.421 & .000 \\
\hline Pelatihan kerja (X2) & .660 & .083 & .695 & 7.973 & .000 \\
\hline
\end{tabular}

Berdasarkan hasil pengujian pada tabel di atas, diperoleh nilai $t$ hitung $>\mathrm{t}$ tabel atau $(7,973>1,995)$, dengan demikian hipotesis kedua yang diajukan bahwa terdapat pengaruh yang signifikan atara pelatihan kerja terhadap kinerja pegawai diterima.

\section{Uji Hipotesis Simultan (Uji F)}

Pengujian hipotesis dengan uji $\mathrm{F}$ digunakan untuk mengetahui hipotesis simultan yang mana yang diterima.

Hipotesis ketiga Terdapat pengaruh yang signifikan antara pengembangan karir dan pelatihan kerja terhadap kinerja pegawai.

Tabel 17. Hasil Uji Hipotesis Pengembangan karir dan Pelatihan kerja Terhadap Kinerja Pegawai.

\begin{tabular}{|c|c|c|c|c|c|c|}
\hline \multicolumn{7}{|c|}{ ANOVA $^{a}$} \\
\hline Model & & Sum of Squares & df & Mean Square & $\mathrm{F}$ & Sig. \\
\hline \multirow[t]{3}{*}{1} & Regression & 565.814 & 2 & 282.907 & 62.758 & $.000^{\mathrm{b}}$ \\
\hline & Residual & 302.028 & 67 & 4.508 & & \\
\hline & Total & 867.843 & 69 & & & \\
\hline
\end{tabular}

Berdasarkan hasil pengujian pada tabel di atas, diperoleh nilai $\mathrm{F}$ hitung $>\mathrm{F}$ tabel atau $(62,758>2,740)$, dengan demikian hipotesis ketiga yang diajukan bahwa terdapat pengaruh yang signifikan atara pengembangan karir dan pelatihan kerja terhadap kinerja pegawai diterima. 


\section{Pembahasan Hasil Penelitian}

\section{Pengaruh Pengembangan Karir Terhadap Kinerja Pegawai}

Dari hasil analisis diperoleh variabel pengembangan karir berpengaruh signifikan terhadap kinerja pegawai dengan nilai korelasi sebesar 0,692 artinya kedua variabel memiliki hubungan yang kuat dengan kontribusi pengaruh sebesar $47,9 \%$. Pengujian hipotesis diperoleh nilai $\mathrm{t}$ hitung $>\mathrm{t}$ tabel atau $(7,902>1,995)$. Dengan demikian hipotesis pertama yang diajukan bahwa terdapat berpengaruh signifikan antara pengembangan karir terhadap kinerja pegawai diterima.

\section{Pengaruh Pelatihan Kerja Terhadap Kinerja Pegawai}

Dari hasil analisis diperoleh variabel pelatihan kerja berpengaruh signifikan terhadap kinerja pegawai dengan nilai korelasi sebesar 0,695 artinya kedua variabel memiliki hubungan yang kuat dengan kontribusi pengaruh sebesar 48,3\%. Pengujian hipotesis diperoleh nilai $t$ hitung $>t$ tabel atau $(7,973>1,995)$. Dengan demikian hipotesis kedua yang diajukan bahwa terdapat berpengaruh signifikan antara pelatihan kerja terhadap kinerja pegawai diterima.

\section{Pengaruh Pengembangan Karir dan Pelatihan Kerja Terhadap Kinerja Pegawai}

Dari hasil analisis diperoleh variabel pengembangan karir dan pelatihan kerja berpengaruh signifikan terhadap kinerja pegawai dengan diperoleh persamaan regresi $\mathrm{Y}=$ $6,909+0,396 \mathrm{X} 1+0,449 \mathrm{X} 2$, nilai korelasi sebesar 0,807 artinya kedua variabel memiliki hubungan yang sangat kuat dengan kontribusi pengaruh sebesar $65,2 \%$ sedangkan sisanya sebesar 44,8\% dipengaruhi faktor lain. Pengujian hipotesis diperoleh nilai $\mathrm{F}$ hitung $>\mathrm{F}$ tabel atau $(62,758>2,740)$. Dengan demikian hipotesis ketiga yang diajukan bahwa terdapat berpengaruh signifikan antara pengembangan karir dan pelatihan kerja terhadap kinerja pegawai diterima.

\section{KESIMPULAN DAN SARAN}

\section{Kesimpulan}

a. Pengembangan karir berpengaruh signifikan terhadap kinerja pegawai nilai korelasi sebesar 0,692 atau kuat dengan kontribusi pengaruh sebesar 47,9\%. Uji hipotesis diperoleh nilai thitung $>t$ tabel atau $(7,902>1,995)$. Dengan demikian terdapat pengaruh yang signifikan antara pengembangan karir terhadap kinerja pegawai pada Dinas Perhubungan Kota Serang.

b. Pelatihan kerja berpengaruh signifikan terhadap kinerja pegawai dengan nilai korelasi sebesar 0,695 atau kuat dengan kontribusi pengaruh sebesar 48,3\%. Uji hipotesis diperoleh nilai thitung $>\mathrm{t}$ tabel atau $(7,973>1,995)$. Dengan demikian terdapat pengaruh yang signifikan antara pelatihan kerja terhadap kinerja pegawai pada Dinas Perhubungan Kota Serang.

c. Pengembangan karir dan pelatihan kerja berpengaruh signifikan terhadap kinerja pegawai dengan nilai korelasi sebesar 0,807 atau sangat kuat dengan kontribusi pengaruh sebesar $65,2 \%$ sedangkan sisanya sebesar $44,8 \%$ dipengaruhi faktor lain. Uji hipotesis diperoleh nilai $\mathrm{F}$ hitung $>\mathrm{F}$ tabel atau $(62,758>2,740)$. Dengan demikian terdapat pengaruh yang signifikan antara pengembangan karir dan pelatihan kerja secara simultan terhadap kinerja pegawai pada Dinas Perhubungan Kota Serang.

\section{Saran}

Berdasarkan pembahasan dan hasil penelitian, maka penulis memberikan beberapa 
saran sebagai berikut:

a. Organisasi harus selalu memberikan semangat dan apresiasi yang layak untuk memastikan pegawai memiliki semangat kerja yang tinggi.

b. Pelatihan harus selalu dilakukan baik menyangkut sistem maupun teknologi agar pegawai memiliki kemampuan yang diharapkan

c. Kinerja organisasi dapat ditingkatkan dengan memberdayakan pegawai dengan menegakkan peraturan yang baik dan pemberian pengembangan karir yang lebih inten lagi

\section{DAFTAR PUSTAKA}

Algifari. (2015). “Analisis Regresi untuk Bisnis dan Ekonomi”. Yogyakarta: BPFE.

Arikunto, Suharsimi (2014). "Prosedur Penelitian Suatu Pendekatan Praktek". Jakarta: Rineka Cipta.

D Sunarsi. (2020). Kepemimpinan Bisnis Strategik. Kota Serang: Desanta Muliavisitama

Edi Sutrisno (2016). Manajemen Sumber Daya Manusia. Jakarta: Prenadamedia Group.

Freed Luthans (2016) Organizational Behavior, McGraw-Hill, New York.

Gerry Dessler (2016) Human Resources Management, Prenticehall, London: International Inc. Handoko (2016) Manajemen Personalia dan Sumberdaya Manusia. Yogyakarta: BPFE.

Harjianto, P. H. (2019). Pengaruh Pengembangan Karier Terhadap Kepuasan Kerja Karyawan Pada PT. Daoben Communication-Kota Tangerang (Studi Kasus Pada Area Dua Wilayah Ciputat Pamulang Dan Serpong). JENIUS (Jurnal Ilmiah Manajemen Sumber Daya Manusia), 2(2), 299-314.

Hasibuan (2016) “Manajemen Sumber Daya Manusia”. Haji Masagung. Jakarta.

Henry Simamora (2005), Manajemen Sumber Daya Manusia, STIE YKPN Bandung.

Imam Ghozali (2017). “Aplikasi Analisis Multivariate Dengan Program SPSS”. Edisi Kelima. Semarang: Badan Penerbit Undip.

Ilham, D. (2014). Implementasi Nilai-Nilai Keagamaan pada Mata Pelajaran Umum dalam Upaya Peningkatan Akhlak Peserta Didik di MAN Malili Kabupaten Luwu

Timur (Doctoral dissertation, STAIN/IAIN Palopo).

Ilham, D. (2019). Implementing Local Wisdom Values in Bride and Groom Course at KUA Bara SubDistrict, Palopo City. Jurnal Konsepsi, 8(1), 1-9.

Ilham, D. (2019). Menggagas Pendidikan Nilai dalam Sistem Pendidikan

Nasional. Didaktika: Jurnal Kependidikan, 8(3), 109-122.

Istijanto (2014) “Riset Sumber Daya Manusia”. Jakarta: PT. Gramedia Pustaka

Kartini Kartono (2011) Pemimpin dan Kepemimpinan, Jakarta: PT. Rajawaligrafindo Persada.

Mangkunegara, Prabu Anwar. (2016). Evaluasi Kinerja SDM. Cetakan ke tujuh, PT Refika Aditama: Bandung.

Nitisemito, Alek.S, (2010), Manajemen Personalia, Ghalia Indonesia, Jakarta.

Rivai Veithzal (2015) Manajemen Sumber Daya Manusia Untuk Perusahaan. Jakarta: PT Raja Grafindo Persada.

Santoso, Singgih (2015). "Menguasai Statistik Multivariat”. Jakarta: PT Elex Media Komputindo.

Sedarmayanti (2016) Manajemen Sumber Daya Manusia, Reformasi Birokrasi dan Manajemen Pegawai Negeri Sipil, Cetakan Kelima, Bandung: PT Refika Aditama.

Siagian, S (2007). Manajemen Sumber Daya Manusia. Jakarta: Bumi Aksara. Sinamo, J. (2011). Delapan Etos Kerja Profesional. Jakarta: Institut

Sudjana (2014) "Metode Statistika”, Bandung: Tarsido.

Sugiyono (2017), "Metode Penelitian Administrasi : dilengkapi dengan Metode $R \& D$ ”. 
Bandung: Alfabeta.

Sunarsi, D. (2019). Penerapan MSDM Strategis Dalam Upaya Meningkatkan Kemampuan Organisasi dalam menyongsong Revolusi 4.0. Jurnal Ilmiah MEA (Manajemen, Ekonomi, \& Akuntansi), 3(1), 221-233. https://doi.org/10.31955/mea.vol3.iss1.pp221$\underline{233}$

Sutrisno, S. (2018). Pengaruh Pelatihan Pelayanan Prima Dan Disiplin Kerja Terhadap Kinerja Karyawan Pada PT. Sumber Sarana. JENIUS (Jurnal Ilmiah Manajemen Sumber Daya Manusia), 2(1). 